\title{
The Effect of Internal Control on the Financial Performance of the North Gorontalo Regency Government
}

\author{
Yanti Aneta ${ }^{1}$, Abdul Wahab Podungge ${ }^{2}$ \\ ${ }^{1}$ Gorontalo State University (email: yanti_aneta@yahoo.com) \\ ${ }^{2}$ University of Gorontalo (email: podunggewahab@gmail.com)
}

\begin{abstract}
This study aims to determine and describe whether there is an influence of internal supervision on the financial performance of the North Gorontalo Regency Government. Design/Methodology/Approach: The sample involved 84 respondents of local government officials from the planning division, and those in charge of activities at all regional organizations in North Gorontalo District-Indonesia. This study used an explanatory method with a quantitative approach. Furthermore, the reflective model measurement used convergent and discriminant validity. In addition, the Partial Least Square-Structural Equation Modeling (PLS-SEM) technique was used as the data analysis.

The results showed that Internal Control had a positive but not significant effect on the Government's Financial Performance of North Gorontalo Regency. The results of data analysis explain that the higher the Internal Control carried out by APIP, the significant value of the influence of the North Gorontalo Regency Government's Financial Performance, on the contrary, the lower the Internal Control carried out by APIP, the lower the significant value of the influence of the North Gorontalo Regency Government's budget performance. The supervision in question is the supervision carried out internally by the local government by the Government Internal Supervisory Apparatus (APIP), and is directly responsible to the regional head of the Regent/Deputy Regent. In carrying out its functions, APIP conducts independent assessments within the organizational unit based on the relevant authority, with the aim of knowing the entire process of activities starting from planning, implementation, programs and activities, until the evaluation of audit reviews, monitoring, and other supervisory activities on the implementation of tasks. and organizational functions.
\end{abstract}

\section{Keywords:}

internal control; performance; local government

\section{Introduction}

In the context of the preparation of the Regional Revenue and Expenditure Budget (APBD), of course it cannot be separated from a process of General Budget Policy (KUA) and Provisional Budget Ceiling Priorities (PPAS) in planning and determining the APBD each year based on the provisions and applicable laws and regulations. The process of policy formulation, especially regarding budgeting, is ideally very important/urgent to do. This is 
due to the phenomenon of APBD policies, in most regions not involving the role of the community in the process of formulating KUA-PPAS so that the budget policies formulated by local governments do not accommodate the needs of the people in the regions. Ideally the form of public participation in the budget policy formulation process here is realized by providing space for public participation in the policy formulation process, especially regarding the budget which is voiced through the Development Planning Consultation (Musrenbang). With this forum, people's aspirations can be captured so that the contents of the policy are representative of the needs of the community at the regional level. The guarantee of a space for public participation in planning is mandated in Law no. 25 of 2004 concerning the National Development Planning System which mandates the existence of a public consultation forum in the development planning process in every government unit. The public consultation forum in the perspective of public policy is part of the policy formulation process to become a policy that will later be implemented.

The importance of budget policy formulation is in line with the opinion of Mardiasmo (2002), namely: "the importance of local government budgets (regional budgets) can be seen from two aspects, namely, 1). The budget is a tool for local governments to direct and ensure sustainable development and improve the quality of life of the community. 2 . The budget is needed because the needs and desires of the community are unlimited and continue to grow, while the available resources are limited. Budget is needed because of limited resources (scarify resources), choice (choice), and trade offs.

In intervening in the implementation of various affairs, regional governments are given the broadest authority and are responsible for managing and determining the regional revenue and expenditure budget (APBD) in accordance with the needs of government affairs. Therefore, the amount of authority and responsibility in question must be managed wisely and carefully while still taking into account the principles of regional financial management, Law 17 of 2003, namely: based on the principles of effective, efficient, economical, transparent and accountable (responsible) budget management by taking into account the principles of justice, propriety, and benefits for the community.

This is also in the opinion of Mardiasmo, (2002) that: "management of regional budgets in improving regional financial performance must be based on the principles of a). Budget Transparency and Accountability. b). Budget Discipline, c). Budget efficiency and 
effectiveness and, d). Budget Format. In principle, regional financial capacity is the most urgent aspect in the administration of regional government affairs, therefore an autonomous region can be said to be able and successful in managing the budget, with all forms of policies for the use of regional revenue and expenditure budgets (APBD) that have been formulated, managed in an orderly, effective, efficient, transparent and accountable (accountable) manner, in the sense that the determination of the posture of public spending (capital expenditures) must be greater than the expenditure on apartur (goods expenditure, honorarium expenditure, official travel expenditure, etc.). Regional governments are also not only able to plan and manage budgets but are also able to transfer all the natural resources potential of each region which is then used as a source of regional income and revenue to finance government programs that are directly related to the public interest. This is in line with Halim's opinion (2001:167) which explains that:

The main characteristics of a region that is capable of implementing autonomy are: 1) regional financial capacity, meaning that the region must have the authority and ability to explore financial sources, manage and use its own finances that are sufficient to finance the administration of its government; and 2) dependence on central assistance must be kept to a minimum, so that local revenue (PAD) can become the largest part of the financial source so that the role of regional governments becomes larger. regions in managing regional finances, how much revenue potential will be optimized.

Table 1.

Trends in Revenue and Percentage of Increase in the Regional Revenue and Expenditure Budget of North Gorontalo Regency in 2014-2018.

\begin{tabular}{llc}
\hline Years & Revenue /APBD & $\begin{array}{c}\text { Percentage } \\
\text { of Increase and Decrease in APBD }\end{array}$ \\
\hline 2014 & $469,971,903,039.00$ & \\
2015 & $559,610,521,971.00$ & 0.19 \\
2016 & $710,998,000,000.00$ & 0.27 \\
2017 & $748,772,997,457.00$ & 18.82 \\
2018 & $721,992,330,522.00$ & 27.96 \\
Total & $1,740,580,425,0100$ & 47.24 \\
\hline
\end{tabular}

Data Source: DPKAD 2014-2019 APBD document

Table 1. above shows that the total regional revenue and expenditure budget (APBD) for 5 (five) years 2014-2018 in intervening various policies, programs and activities of the 
North Gorontalo Regency Government is Rp.1,740,580,425,0100 Trillion. The budget, if observed every year, has increased, although not significantly. As was the case in 2014, the regional revenue and expenditure budget (APBD), only amounted to Rp.460,425,281,994 billion, an increase of Rp.559,610,521.971.00, or 0.19\% in 2015. Then in 2016 the APBD was Rp.710,998,000,000.00 or 0, 27\%, an increase of Rp.748,772,997,457.00 in 2017 or $18.82 \%$, and in 2018 a slight decrease from the previous budget of Rp.721,992,330,522.00 or $27.96 \%$ of the previous budget.

The importance of internal control aims that the results of the implementation of activities can be efficient (efficient) and effective (effective), in accordance with a predetermined plan. All organizational activities must be supervised by good, effective and efficient supervision which must be carried out systematically. Systematic monitoring will provide optimal results. According to Kusnadi et al (2002:265), the objectives of supervision generally include: a) Measurement of compliance with applicable policies, plans, procedures, regulations and laws; b) Maintaining the resources owned by the organization; c) Achievement of the goals and objectives set by the organization; d) The trustworthiness of information and the integration of existing information within the organization; e) Ongoing performance and then compare the actual performance with the standard and increase the deviation rate and then look for the right solution.

According to Sondang P. Siagian (2005: 152): “Supervision must be comprehensive in the sense that no single implementation of operational activities should escape the target and scope of supervision. In order for supervision to be carried out effectively, in the sense of succeeding in factually finding things that occur in the implementation of all operational activities, both positive and in the form of deviations, deviations, or errors, various instruments are needed, such as: 1) Standard results that are planned to be achieved Are the targets to be achieved in an activity that must be used as a guide in all operational activities; 2) Budget The budget is a monitoring instrument because it is easy to know how much funds are available to finance certain activities, such as purchasing the necessary equipment and paying wages and salaries; 3) Statistical data Statistical analysis of various operational aspects of an organization is a very important monitoring tool for management; 4) Report The report is used as an instrument of supervision if the supervision is carried out remotely, the report can be in the form of a written report and can also be an oral report; 5) Auditing Auditing is a 
systematic verification effort aimed at various operational and organizational aspects, auditing can be aimed at the personnel, logistics and financial sectors; 6) Direct observation The use of direct observation can be implemented as a monitoring technique, namely: a) Managers see directly the implementation of operational activities carried out by their subordinates; b) Psychological in the sense that subordinates will feel cared for by their superiors.

The next researcher focuses this article on indicators of internal control $(\mathrm{X})$, including: 1) Control Environment; 2) Risk Assessment; 3) Control Activities; 4) Information and Communication; and 5) Internal Control Monitoring. Furthermore, regional financial performance indicators (Y) which include: 1) Effectiveness; 2) Efficiency; 3) Accountability; and 4) Transparency.

\section{Methods}

The object of the research is the regional apparatus organization within the Gorontalo Regency Government of North-Indonesia. Furthermore, an explanatory method with a quantitative approach is used which is useful for analyzing the relationship between variables through hypothesis testing (Creswell and Creswell, 2018). In addition, this research is descriptive and verification using survey technique. Population refers to government regulation no. 18 (2016) regarding regional apparatus, North Gorontalo Regency regional regulation no. 7 (2016) which is explained in detail through Regent Regulation no. 45 (2016) concerning the composition and number of officials in regional apparatus organizations.

This study is based on a survey that aims to test several hypotheses. The population is determined based on the number of officials who have served as technical implementers and in charge of all regional apparatus organizations, namely 514 people. Based on the population, the sample size was calculated using the Slovin (1960) formula, namely 84 respondents with a sampling error of $10 \%$. The data collection instrument also use a quantitative method in the form of a questionnaire. The technique used is primary data through questionnaires and direct interviews. While secondary data includes studies of journals, textbooks, conferences, reports on budget planning and realization documents, budget work plans, regional government work plans, regional revenue and expenditure budget documents. In addition, it includes a 
study of statutory regulations, ministerial regulations, technical guidelines, regional regulations, and regional head regulations related to research variables.

The Partial Least Square-Structural Equation Modeling (PLS-SEM) approach was used for data analysis because it allows minimal data measurement and relatively small sample size (Chin et al., 2003; Hair et al., 2006). Furthermore, the validity, reliability, and the relationship between variables were tested using the Cronbach coefficient (1963). Based on the conceptual framework, this research consists of two exogenous variables, namely internal control (X1), while the endogenous variable is financial performance (Y2). In addition, the indicators used are reflective models. Structural model evaluation was used to determine the significance of the relationship between constructs (Fornell and Larcker, 1981). The exogenous latent variable measurement model $\mathrm{X} 1$ uses 3 dimensions, namely the control environment, risk assessment, internal control activities, information and communication, and internal control monitoring with 11 measurement indicator questions. Furthermore, the exogenous latent variable $\mathrm{X} 2$ has 2 dimensions, namely the effectiveness of regional finance and regional financial efficiency with 14 question indicators.

\section{Results and Discussion}

The results of the hypothesis test explain that Internal Control has a positive but not significant effect on the Financial Performance of the North Gorontalo Regency Government, where the $t$-statistic value generated is greater than the $t$-table value determined in this study, which is $0.992(>1.96)$. at the $5 \%$ alpha level. The results of this test mean that the Financial Management Performance of the Government of North Gorontalo Regency, becomes more effective, efficient, transparent and accountable if the supervision pattern of the Government Internal Supervisory Apparatus (APIP) is carried out properly. However, if the pattern of the Government Internal Supervisory Apparatus (APIP) is not implemented properly, it tends to cause many problems such as budget wastage, personnel expenditures are still larger than the portion of capital expenditures. Absorption of the budget is not optimal, frequent findings are repeated, budget irregularities and other problems that result in the fulfillment of public rights being sidelined.

The importance of Internal Control is carried out on the Performance of Budget Management so that there is no inefficiency or budget leakage. According to Sabeni and 
Gozali (1997) the essence of supervision is to prevent as early as possible the occurrence of irregularities, waste, abuse, obstacles, errors and failures in achieving goals and carrying out organizational tasks. Meanwhile, according to Effendi, (2005:4). Supervision is an action or activity to ensure that the implementation of an activity does not deviate from a predetermined plan with the main purpose of supervision not to find fault but to direct the implementation of activities so that the predetermined plan can be carried out optimally.

Furthermore, according to Government Regulation No. 60 of 2008 internal control is: “The entire process of auditing, reviewing, evaluating, monitoring, and other supervisory activities on the implementation of organizational tasks and functions in order to provide adequate assurance that the activities have been carried out in accordance with the established benchmarks. has been determined effectively and efficiently for the benefit of the leadership in realizing good governance.

The importance of Internal Control on regional financial management as the opinion of the experts described above, is also supported by several previous research journals that have a close relationship with hypothesis testing including research conducted by, Research conducted by Marus Eton et al (2018), reveals that the internal control system affects financial accountability. Research conducted by Cecilia Lelly Kewo (2017), where higher internal control will increase the financial accountability of district/city government institutions in Indonesia. In other words, it can be interpreted that managerial performance can be improved if the government tool unit (SKPD) further improves the implementation of internal control, Research conducted by Eko Suyono and Eko Hariyanto (2012), Internal control has an effect on the financial performance of the Bandung Regency government, Research conducted by Sukma Listari et al, (2018) The Government's Internal Control System has a positive and significant effect on the implementation of Good Governance. Research conducted by Almanda Primadona (2014) shows that internal control has a significant effect on the performance of the Bandung City government, and research conducted by Mohamed Hassan Abdullahi (2016) that the relationship described between internal control (Information and Communication systems, internal audit and monitoring) and financial performance has a significant influence. 
The influence of supervision on the competence of the apparatus and the modeling of internal control on planning supported by competent human resources is not only limited to testing hypotheses or modeling which is supported by theory, expert opinions, and some related previous research findings, but according to the researcher a commitment from regional leaders is needed in implementing modeling as a solution for handling problems based on research findings as follows:

The need for APIP to socialize PP regulation number 60 of 2008 concerning the government's internal control system, where the purpose of SPIP socialization is basically to provide guidance and increase the knowledge of planning officials and regional financial managers to better understand and have awareness and concern about risks and how to manage the risks faced organizations within the limits of their respective powers, with the hope that there will be no findings that result in the risk of state losses. This is in accordance with the responses of respondents where as much as $84.48 \%$, respondents want the need for socialization of government regulation No. 60 of 2008. Besides that, it is not only necessary to socialize the regulations in question, but also to strengthen the internal control environment, especially in the scope of risk analysis, and to measure the impact of the risk of failure of program/activity implementation and budgeting in order to minimize findings. According to the researcher, several strategies are important to be carried out by the North Gorontalo Regency Government related to risk management, including: 1) Identifying risks. Risk identification is carried out to identify what risks are faced by an organization/OPD; 2) Conduct Evaluation. to risk The purpose of risk evaluation is to better understand the characteristics of the risk. If we gain a better understanding, then the risk will be easier to control. A more systematic evaluation is carried out to measure these risks; 3) Risk Measurement, and Risk Management. After risk analysis and evaluation, the next step is to manage risk. Risk must be managed. If the organization fails to manage risk, the consequences can be quite serious

From several opinions and supported by several previous studies as described above, basically regional financial management which begins with the stages of planning, implementing, monitoring and evaluating, as well as supervision that is carried out properly, integrated, effectively and efficiently from the beginning to the end of the implementation of programs and activities will have an impact to increase the welfare of the people. In this study, 
what is meant by supervision of local government financial performance is the supervision carried out by the Government Internal Supervisory Apparatus (APIP) which is carried out through the application of the Government Internal Supervision System (SPIP) as stated in the Government Regulation of 60 of 2008 concerning the Internal Control System, which includes the following elements: 1) Control Environment with a strong commitment from the leadership and all parties to make SPIP a means to achieve better organizational goals; 2) Risk Assessment with documented mapping; 3) Control activities with the implementation of a review become a reference in evaluating for improvements for the coming year; 4) Information and Communication by carrying out new innovations in the application of information technology by immediately realizing plans for making information systems for financial management at Puskesmas and other UPTs, and 4) Monitoring, taking into account recommendations for follow-up monitoring by APIP so that the effectiveness of achieving organizational goals can be achieved. materialized.

According to COSO in Hariayanto Jusup (2001:257); Messier (2000: 188), said that internal control has 5 components, namely: 1) Control environment ();2) Risk interpretation 3) Accounting information and communication systems; 4) Control activities; and 5) Monitoring. With the implementation of the Government Internal Supervision System (SPIP) as stated in the Government Regulation of 60 Year 2008 of course, it is hoped that it can be implemented well in the regions. Therefore, a joint commitment is needed in the implementation of the Government Internal Control System (APIP) in the regions starting from the leadership to all employees who are at the level of implementing administrators to the level of Primary Leadership, where the implementation is continuous and sustainable, starting from planning, monitoring, implementation, to implementation. accountability runs in an orderly, controlled and effective and efficient manner. The successful implementation of these regulations is not only supported by the commitment of Internal OPD officials but the Inspectorate with all its powers based on the legislation must play an active role in ensuring that the implementation of SPIP is managed.

The regional government has been running well in accordance with the provisions/guidelines as well as conducting regular monitoring so that the implementation of programs/activities can run effectively and efficiently, which in turn has an impact on the budget management performance reporting system giving a very good impact on the 
predicate of Unqualified Opinion. There are several problems as well as research findings that cause the implementation of SPIP not to run optimally in North Gorontalo Regency so that it needs to be followed up and made improvements in the future by the North Gorontalo Regency Government, as well as research findings on the influence of Organizational Commitment on the development of Apparatus Competence in preparing the Renja-RKA Planning in the OPD that must be followed up, in order to make future improvements include the following:

First, the monitoring of internal control on evaluating the success of program planning/budgeting and activities, as part of the implementation of government regulation No. 60 of 2008 in North Gorontalo Regency has not run optimally, where as many as $81.90 \%$ of respondents want an evaluation of the success rate of program planning and budgeting and activities in OPD, so that the public/community can feel the benefits of implementing programs and activities. This is done as an effort to determine the extent of success and failure in the implementation of a program and activity which later the results of this evaluation can be used as a recommendation to be followed up by stakeholders in making a policy (Decision maker) in making decisions whether the program and its activities are the implemented activities are appropriate and still appropriate or feasible to continue or are still lacking, so that revisions, future improvements are needed or even it is decided not to continue.

Second, there has not been socialization of the risk assessment of the program and activity budget allocation policy, of which $75.24 \%$, respondents assessed that so far APIP has not been optimal in terms of conducting guidance and supervision either through socialization of risk control. )/Inspectorate socialize in OPD how to conduct risk analysis, and measure the impact of failure risk in program/activity implementation and budgeting in order to minimize findings. The risk assessment referred to here is to see the compatibility between the goals, objectives and targets of programs and activities carried out by each OPD in one fiscal year, so that the implementation of programs and activities is carried out effectively, efficiently, transparently and accountably based on the vision and mission of the organization. This is in accordance with Government Regulation (PP) Number 60 of 2008 concerning the Government's Internal Control System (SPIP), especially in the third part of article 13 paragraph (1), which states that: "Leadership of government agencies is required to conduct a risk assessment. In Government Regulation No. 60 of 2008, article 13, it is stated that risk 
assessment is an activity of assessing the possibility of events that threaten the achievement of the goals and targets and targets of government agencies. Furthermore, the government regulation states that risk assessment consists of risk identification and risk analysis". Thus, the determination of the objectives of implementing programs and activities, the regional inspectorate as an element of organizing the government's internal supervisor (APIP) in the region is required to identify internal and external risks that can affect the success of achieving the goals, objectives and targets of each OPD based on the vision and mission in order to obtain risks. which has a very high probability of occurrence and impact to a very low risk.

Third, the achievement of the vision and mission of the regional head as set out in the 5-year RPJMD document includes the objectives and targets of programs and activities, strategies and policies for budget allocation for programs and activities, as well as regional strategic program priorities that have not yet taken into account the ability of budgeting to finance regional needs. Therefore, it is necessary for APIP's role to be more optimal in monitoring the control of the realization of the achievement of OPD performance indicator targets and regional performance indicator targets, by revising/reviewing the nonachievement of the targets that have been planned into a planning document that has been prepared and planned for. five year period. This is in accordance with the responses of respondents where as many as $79.76 \%$. respondents want the internal control apparatus (APIP) to revise/review/change the indicators and measures of achievement of targets for the success of program/activity performance in the OPD according to the needs and budget capabilities of each OPD. Monitoring of Internal Control System in dil implement through continuous monitoring, separate evaluation, and follow-up on recommendations from audit results and other reviews. Continuous monitoring is carried out through routine management activities, supervision, comparison, reconciliation, and other related actions in the implementation of tasks. Separate evaluation is carried out through self-assessment, review, and testing of the effectiveness of the Internal Control System which can be carried out by government internal control officials or government external parties using the internal control test list.

Fourth, the socialization of ethical guidance and supervision and the principles of effective, efficient, transparent and accountable budget management by the government internal control apparatus (APIP) has not been optimal. This is in accordance with the 
responses of respondents where as many as $79.76 \%$. respondents want guidance at the level of echelon IV and III officials on the importance of implementing integrity and ethical values, in budget management, as a form of implementing environmental control through socialization, oral communication, etc. Internal control (APIP) not only helps monitor whether the local government has done what it should be doing, utilizes the budget in accordance with the planned objectives, and complies with applicable laws and regulations (oversight), but also provides consulting or coaching services in in order to improve the performance of government budget management and be able to identify trends/developments and challenges that will be faced by the government (foresight).

From the results of the assessment of respondents' perceptions of several indicators of internal control that affect the performance of regional financial management, it can be concluded by researchers that there is a need for Government Internal Supervisory Apparatus (APIP) to continuously make improvements and changes in carrying out the internal control process more effectively, efficiently in carrying out its functions effectively. independent based on the relevant authority, with the aim of knowing the entire process of activities starting from planning, implementation, programs and activities, until the evaluation of audit reviews, monitoring, and other supervisory activities on the implementation of organizational tasks and functions in order to provide adequate assurance that programs and activities have been implemented. carried out in accordance with predetermined benchmarks and planned into a planning document. In addition, according to researchers, it is necessary for APIP in the area to build intense communication with OPD and BPKP as Regency/City SPIP coaches as an effort to carry out SPIP development starting from increasing capacity building, conducting training to equalize perceptions of all OPDs, coordinating with each other, conducting periodic evaluations through meetings., being a consultant and providing understanding in solving OPD problems, as well as providing information through socialization about SPIP in every supervisory activity in the area, especially in the North Gorontalo Regency area.

Based on Presidential Decree Number 74 of 2001 concerning Procedures for Supervision of Regional Government Administration. Article 1 paragraph (6) states that regional government supervision is a process of activities aimed at ensuring that regional governments run in accordance with the plans and provisions of applicable laws and 
regulations. Supervision According to Fatchurrochman (2002) can be divided into two, namely:

1. Internal supervision which consists of inherent supervision and functional supervision. Inherent supervision is supervision carried out by the leader or direct supervisor of an organization on the performance of subordinates with the aim of knowing or assessing whether the work that has been determined has been carried out in accordance with the provisions or laws and regulations that apply. This supervision is also known as APIP (Government Internal Supervisory Apparatus). APIP consists of BPKP (Financial and Development Supervisory Agency), Inspectorate General Department (Irjen) or NonDepartmental Institution Supervisory Unit, Regional Inspectorate (Itwil), and Internal Supervisory Unit (SPI). Embedded supervision is supervision carried out by the leader or direct supervisor of an organization on the performance of subordinates with the aim of knowing or assessing whether the work specified has been carried out as directed. in accordance with the provisions or applicable laws and regulations. Meanwhile, functional supervision is internal supervision carried out by functional officers, both from the internal environment of departments, state institutions or state-owned enterprises, including supervision from special supervisory institutions.

2. Direct supervision is carried out personally by observing, researching, checking, selfchecking at work and asking directly from the executor by means of inspection. Meanwhile, indirect supervision is carried out by studying the reports received from the executor. Preventive supervision is carried out through pre-audit, namely before work begins. Repressive supervision is carried out through a post audit with an on-site inspection (inspection).

3. The supervision carried out by the DPRD on the executive is intended to guarantee the creation of a regional budget management pattern that avoids collusion, corruption and nepotism $(\mathrm{KKN})$ practices, starting from the planning, ratification, implementation and accountability processes. Besides the DPRD directly overseeing the budget mechanism, the DPRD also uses an external government supervisory apparatus, which is independent of the regional executive body, namely the Supreme Audit Agency (BPK).

From the definition above, it can be concluded by the researcher that "Internal Control is one part of internal control activities that function to carry out independent assessments 
carried out by people or agencies / institutions within the organizational unit environment based on the relevant authority, with the aim of knowing the entire process of activities starting from planning, implementation, programs and activities, until the evaluation of audit reviews, monitoring, and other supervisory activities on the implementation of organizational tasks and functions as an effort to provide adequate assurance that programs and activities have been implemented in accordance with the planned benchmarks and determined effectively, efficiently, and if necessary, implement corrective actions so that the work results are in accordance with the predetermined plan as an effort to realize the achievement of an organization's success based on the vision and mission that has been set, where the main elements of supervision/control consist of, Control Environment, Risk Assessment, Accounting information and communication systems, Control Activities and Monitoring.

Figure 3.2

Research Result Framework

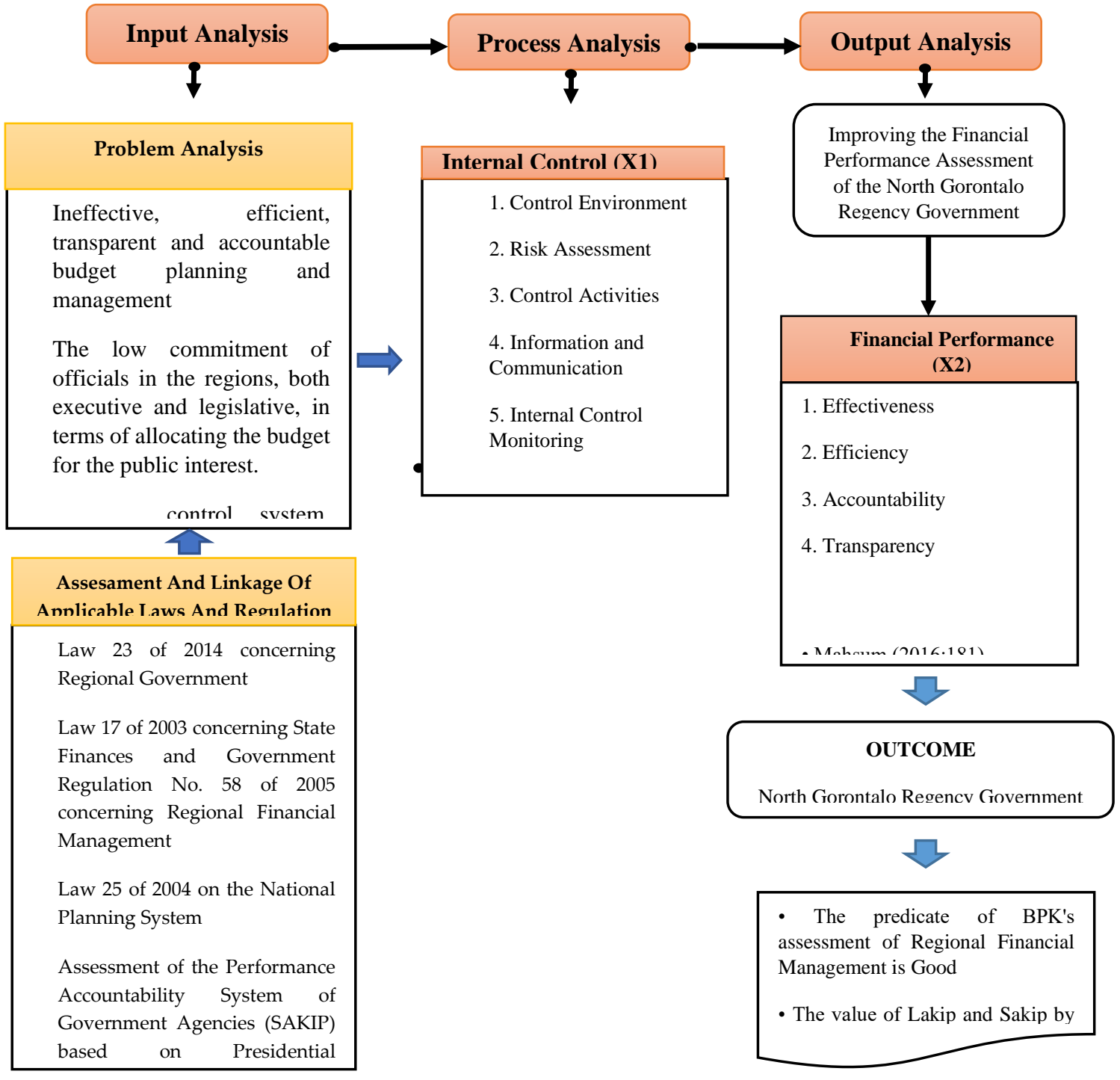




\section{Conclusion}

Based on the results and discussion that the researchers described above, the conclusions in this article are:

1. Internal Control has a positive but not significant effect on the Financial Performance of the North Gorontalo Regency Government. The results of data analysis explain that the higher the Internal Control carried out by APIP, the significant value of the influence of the North Gorontalo Regency Government's Financial Performance, on the contrary, the lower the Internal Control carried out by APIP, the lower the significant value of the influence of the North Gorontalo Regency Government's budget performance. The supervision in question is the supervision carried out internally by the local government by the Government Internal Supervisory Apparatus (APIP), and is directly responsible to the regional head of the Regent/Deputy Regent. In carrying out its functions, APIP conducts independent assessments within the organizational unit based on the relevant authority, with the aim of knowing the entire process of activities starting from planning, implementation, programs and activities, until the evaluation of audit reviews, monitoring, and other supervisory activities on the implementation of tasks. and organizational functions as an effort to provide adequate assurance that programs and activities have been implemented in accordance with the planned and established benchmarks effectively, efficiently, and if necessary, APIP implements corrective actions so that the work results are in accordance with the plans that have been set as an effort encourage the performance of the North Gorontalo Regency Government's Budget to get better.

2. Internal Supervision has a positive and significant effect on Apparatus Competence. The results of this analysis mean that planning and budgeting supported by ASN/Employees who have competence in terms of knowledge, skills and attitudes will be of good quality if from the beginning it involves the role of the Government Internal Supervisory Apparatus (APIP). in the process of planning stages it will prevent inefficiency of failure in building. On the other hand, if planning and budgeting are designed and compiled without involving APIP's role as internal control, and are not supported by unqualified human resources, it will result in "some loss" or inefficiency in existing development programs in the area. In the Planning and Budgeting Process, development programs 
are essentially carried out in an integrated manner, through a planning and budgeting approach from the previous Money Follows Program, to a Money Follows Function, by carrying the concept of THIS approach (thematic, holistic, integrative and spatial), so that the output of development planning and budgeting is more result oriented efficiently, effectively and transparently and accountably.

\section{Suggestions}

Based on the conclusions and implications of the research above, the following suggestions can be put forward: To improve the performance of regional financial management which is planned annually based on the mechanism of political, technocratic, participatory and bottom-up approaches (bottom-up) and top-down approaches ( top-down), well managed by taking into account the principles of budget management as regulated in Law 17 of 2003 concerning State Finances article 3, and Law 23 of 2014 concerning Regional Government article 1, mandates that in the management of regional finances, implemented effectively, efficiently, transparently, and accountably and with due regard to a sense of justice and propriety. This is done as an effort to realize the vision and mission of the regional head, regent/deputy regent in implementing the programs and activities that have been promised to the community. In addition, the Government of North Gorontalo Regency is deemed necessary to make improvements in internal budget management based on respondents' responses, which are then analyzed by researchers including:

1. Accountability dimension with assessment items, respondents on the importance of each OPD measuring the achievement of program/activity implementation, so that the public/community can feel the impact of success or failure on the implementation of programs and activities, as an effort to support accountability of the planning process and accountability of allocation policies budget

2. Transparent dimension with assessment items, respondents to the obligations in each OPD in terms of implementing transparency, good use of the budget including targets, objectives and budget utilization, into the general budget policy (KUA) so that the regional revenue and expenditure budget (APBD) does not only allocate or accommodate political interests and the interests of regional apparatus organizations (OPD) 
3. Dimensions of Budget Efficiency (effectiveness), with the items of respondents' assessment of the implementation of the budget allocation policy the program/activity budget in the OPD Renja-RKA document applies at least $\pm 70 \%$ of the APBD budget for public/community spending, and $\pm 30 \%$ for apparatus expenditure or $\pm 60 \%$ for public/community expenditure and $\pm 40 \%$ for apparatus

\section{References}

\section{Books and Journal:}

Abdullahi, M. H., Abdullahi, M. H., \& Muturi, W. (2016). Effect Of Internal Control Systems On Financial Performance Of Higher Education Institutions In Puntland. International Journal Of Economics, Commerce And Management, 4(12).

Bosenberg, M., Muthusamy, V., Curley, D. P., Wang, Z., Hobbs, C., Nelson, B., ... \& Chin, L. (2006). Characterization Of Melanocyte-Specific Inducible Cre Recombinase Transgenic Mice. Genesis, 44(5), 262-267.

Cronbach, L. J., Rajaratnam, N., \& Gleser, G. C. (1963). Theory Of Generalizability: A Liberalization Of Reliability Theory. British Journal Of Statistical Psychology, 16(2), 137163.

Creswell, A., White, T., Dumoulin, V., Arulkumaran, K., Sengupta, B., \& Bharath, A. A. (2018). Generative Adversarial Networks: An Overview. IEEE Signal Processing Magazine, 35(1), 53-65.

Fornell, C., \& Larcker, D. F. (1981). Structural Equation Models With Unobservable Variables And Measurement Error: Algebra And Statistics.

Halim, Abdul Dan Muhammad Syam Kusufi. 2012. Teori, Konsep, Dan Aplikasi Akuntansi Sektor Publik. Jakarta. Salemba Empat.

Kewo, C. L. (2017). The Influence Of Internal Control Implementation And Managerial Performance On Financial Accountability Local Government In Indonesiaf. International Journal Of Economics And Financial Issues, 7(1), 293-297.

Kusnadi, Dkk. 2002. Pengantar Manajemen. Malang : Universitas Brawijaya.

Mardiasmo, 2002. Akuntansi Sektor Publik Penerbit Andi Yogyakarta

Mulyana, M. (2010). Manajemen Sumber Daya Manusia (Sdm) Ritel Dalam Meningkatkan Kinerja Perusahaan. Jurnal Ilmiah Ranggagading, 10(2), 164-170. 
Podungge, A. W., \& Aneta, A. (2020). Profesionalisme Pegawai Ditinjau Dari Aspek Pengorganisasian Dalam Pelayanan Publik. Publik (Jurnal Ilmu Administrasi), 9(1), 5565.

Robby, H., \& Abdul, P. W. (2020). The Existence Of Management Policies And Practices For The Information Of Regional Regulations On Development Progress In Bone Bolango Regency.

Sabeni, Arifin Dan Imam Ghozali, 1997. Akuntansi Pemerintahan. Yogyakarta: Penerbit: BPFE Yogyakarta.

Slovin, E. (1960). Slovin's Formula For Sampling Technique. Retrieved On February, 13, 2013.

Suyono, E., \& Hariyanto, E. (2012). Relationship Between Internal Control, Internal Audit, And Organization Commitment With Good Governance: Indonesian Case. China-USA Business Review, 11(9).

Siagian, Sondang. 2005.Manajemen SDM. Jakarta: Bumi Aksara.

\section{Regulations:}

Undang-Undang No. 25 Tahun 2004 Tentang Sistem Perencanaan Pembangunan Nasional Undang-Undang Nomor 23 Tahun 2014 Tentang Pemerintahan Daerah Undang-Undang 17 Tahun 2003 Tentang Keuangan Negara

Peraturan Pemerintah (PP) Nomor 58 Tahun 2005 Tentang Pengelolaan Dan Pertanggungjawaban Anggaran

Peraturan Pemerintah Nomor 60 Tahun 2008 Tentang Sistim Pengendalian Intern Pemerintah Keputusan Presiden Nomor 74 Tahun 2001 Tentang Tata Cara Pengawasan Penyelenggaraan Pemerintah Daerah.

Peraturan Daerah Kabupaten Gorontalo Utara Nomor 72016 Tentang Pelayanan Publik 